JURNAL TERKNOSAINS

VOLUME 1

No. 2, 22 Juni 2012

Halaman 71-143

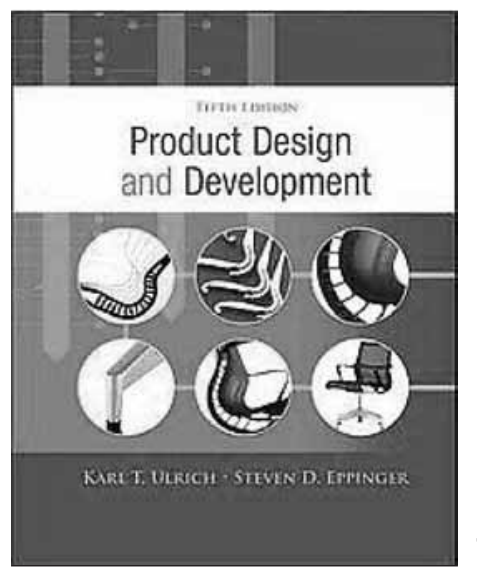

\title{
RESENSI BERMULA DARI MIMPI MEWUJUDKAN INOVASI
}

\author{
Muhammad Kusumawan Herliansyah \\ Staf Pengajar Jurusan Teknik Mesin dan Industri, Fakultas \\ Teknik, Universitas Gadjah Mada dan Peneliti Produk \\ Bioceramics Untuk Aplikasi Biomedis \\ Judul Buku : : Product Design and Development \\ Penulis \\ : Karl T. Ulrich dan Steven D. Eppinger \\ Penerbit \\ : McGraw-Hill Companies \\ Edisi \\ $: 5$ \\ Tahun : 2012 \\ Tebal : 415 halaman
}

Kemakmuran suatu bangsa tergantung pada kemampuannya memanfaatkan sumbersumber alam dan mengembangkan serta memproduksi suatu produk. Bahkan kemampuan mengembangkan serta memproduksi suatu produk merupakan komponen terpenting penentu tingkat kemakmuran ekonomi suatu bangsa. Bukti-bukti telah menunjukkan banyak bangsa-bangsa di dunia yang miskin sumber alam, tetapi memiliki tingkat kemakmuran yang tinggi karena keunggulannya dalam kemampuan mengembangkan serta memproduksi produk-produk baru dan unggul.

Dari sejarah juga terlihat bahwa manusia senantiasa berusaha untuk meningkatkan nilai-nilai kehidupan dan taraf hidupnya. Hal itu terjadi karena manusia selalu berusaha untuk mencapai kenyamanan dan kemudahan dalam hidupnya. Mimpi-mimpi dan harapanharapan untuk meraih kenyamanan dalam hidup itulah yang kemudian mendorong manusia untuk menggunakan seluruh potensi yang dimilikinya untuk mewujudkan inovasi-inovasi sepanjang hidupnya yang pada akhirnya akan melahirkan berbagai produk yang dapat menopang kemudahan hidup manusia. Pada dasarnya proses pengembangan produk adalah urutan langkah-langkah atau aktivitas yang digunakan oleh seseorang atau suatu perusahaan untuk menyusun, merancang, dan mengkomersilkan sebuah produk. Proses ini berlangsung terus-menerus sebagai sebuah siklus untuk mendapatkan produk yang paling unggul, produk yang paling murah, produk yang paling mudah dibuat, produk yang paling cepat dihasilkan, dan lain sebagainya. Dengan kata lain diperlukan suatu langkah-langkah sistematis untuk menghasilkan produk yang sukses baik dari sudut pandang customer maupun dari sudut pandang investor atau industri. 


\section{Karakteristik Pengembangan Produk yang Sukses}

Dari sudut pandang investor yang selalu mengupayakan keuntungan bagi perusahaannya, hasil proses pengembangan produk yang sukses adalah produk yang dapat dibuat dan menguntungkan ketika dijual, walaupun kadangkala keuntungan adalah sesuatu yang sulit diukur secara langsung dan dalam waktu yang cepat. Oleh karena itu, seringkali digunakan lima dimensi yang lebih spesifik (yang pada akhirnya juga berhubungan dengan keuntungan) untuk mengukur performance usaha pengembangan produk yang telah dilakukan. Kelima dimensi tersebut sebagai berikut:

a. Product Quality: Seberapa bagus produk yang dihasilkan dari usaha pengembangan produk yang telah dilakukan? Apakah produk yang dihasilkan benar-benar dapat memenuhi kebutuhan customer? Apakah produk yang dihasilkan robust dan reliable? Kualitas dari produk yang dikembangkan benar-benar menggambarkan market share dan level harga yang akan dibayar oleh customer sebagai penghargaan terhadap nilai-nilai yang ada pada produk yang telah dikembangkan tersebut.

b. Product Cost: Apa sajakah yang termasuk dalam biaya produksi sebuah produk? Biaya ini termasuk biaya-biaya yang dikeluarkan untuk peralatan dan tooling sebagaimana halnya kenaikan biaya produksi untuk setiap unit produk yang dihasilkan. Biaya produk menyatakan seberapa banyak keuntungan perusahaan akan bertambah untuk setiap bagian volume penjualan dan setiap bagian harga penjualan.

c. Development Time: Seberapa cepat tim menyelesaikan proses pengembangan produk? Waktu pengembangan menunjukkan seberapa resposif perusahaan dapat dipaksa untuk lebih kompetitif dan untuk melakukan pengembangan teknologi sebagaimana seberapa cepat perusahaan menerima economic returns dari pengorbanan yang telah dilakukan oleh tim pengembangan produk.

d. Development Cost: Seberapa banyak modal yang telah dikorbankan perusahaanuntuk proses pengembangan produk? Biaya pengembangan biasanya merupakan bagian penting dari modal yang dikeluarkan untuk menghasilkan keuntungan.

e. Development Capability: Apakah tim dan perusahaan lebih baik dapat mengembangkan produk pada masa yang akan datang sebagai hasil dari pengalaman mereka dengan proyek pengembangan produk? Pengembangan kemampuan merupakan aset perusahaan yang dapat digunakan untuk mengembangkan produk secara lebih efektif dan ekonomis di masa yang akan datang

\section{Tantangan-Tantangan dalam Pengembangan Produk}

Mengembangkan produk yang hebat adalah sebuah pekerjaan yang berat, Hanya sejumlah perusahaan saja yang mampu melakukannya. Beberapa karakteristik yang menjadikan proses pengembangan produk menjadi demikian menantang di antaranya sebagai berikut:

a. Trade-offs: Dalam setiap produk yang dikembangkan akan selalu muncul trade-off, sebagai contoh sebuah produk pesawat terbang dapat dibuat lebih ringan, namun hal itu akan berdampak pada biaya produksinya. Satu hal yang dipandang sebagai aspek yang paling sulit dalam pengembangan produk adalah pengenalan, pemahaman dan pengelolaan berbagai trade-off yang muncul sepanjang pengembangan produk sehingga dapat memaksimalkan sukses pada produk yang tengah dikembangkan.

b. Dinamics: Teknologi semakin meningkat, pilihan-pilihan customer semakin 
berkembang, para pesaing berlomba mengenalkan produk-produk barunya dan macroeconomic environment terus berubah secara dinamik. Pengambilan keputusan yang tepat ditengah lingkungan yang selalu berubah adalah merupakan kebutuhan yang tidak dapat dielakkan.

c. Details: Pengembangan produk senantiasa membutuhkan keputusankeputusan hingga pada level yang sangat detil. Keputusan pada satu bagian akan menimbulkan dampak munculnya tuntutan untuk mengambil keputusan yang lain.

d. Time Pressure: Dalam proses pengembangan produk berbagai keputusan dari level yang umum hingga level detil harus diambil dengan cepat dan sering kali keputusan harus berdasarkan data-data yang sangat terbatas.

e. Economics: Pengembangan, pembuatan, dan pemasaran sebuah produk baru memerlukan investment yang besar. Untuk mendapatkan keuntungan yang wajar dari investasi tersebut, produk akhir yang dihasilkan harus memenuhi kebutuhan dan menarik customer untuk memilikinya selain itu juga relatif tidak mahal untuk diproduksi.

Bagi sejumlah orang, perancangan dan pengembangan produk benar-benar merupakan proses yang sangat menarik karena terdapat sejumlah tantangan di dalamnya. Selain itu sejumlah intrinsik attribut juga memiliki kontribusi terhadap munculnya daya tarik tersebut, seperti:

a. Creation: Proses pengembangan produk dimulai dengan sebuah ide dan diakhiri dengan pembuatan sebuah wujud fisik. Ketika dilihatsecara keseluruhan maupun dari sisi aktivitas individual, proses pengembangan produk merupakan proses yang benar-benar kreatif

b. Satisfaction of Societal and Individual Needs: Semua produk yang dikembangkan dalam kerangka untuk memenuhi berbagai kebutuhan. Ketertarikan individu dalam pengembangan produk-produk baru hampir selalu mendapatkan jalan keluarnya dan dapat pula mengembangkan produk yang diinginkan guna memenuhi kebutuhan-kebutuhan penting.

c. Team Diversity: Keberhasilan proses pengembangan produk memerlukan berbagai keahlian dan bakat yang berbeda-beda. Sebagai hasilnya, tim pengembang melibatkan individuindividu dengan latar belakang pendidikan, pengalaman, perspective dan personality yang sangat beragam, justru keberagaman itulah yang pada akhirnya menghasilkan kesuksesan pengembangan produk.

d. Team Spirit: Tim pengembangan produk selalu memiliki motivasi yang tinggi dan merupakan group yang sangat cooperative. Anggota-anggota tim dapat ditempatkan pada satu lokasi sehingga dapat memfokuskan energi kolektif untuk pembuatan produk. Situasi ini dapat menghasilkan jalinan persahabatan yang kuat antara anggotaanggota tim pengembangan produk.

\section{Proses Pengembangan Produk}

Secara umum/generic, proses pengembangan produk terdiri atas enam phase. Proses diawali dengan phase perencanaan/planning. Tahap ini sering pula disebut sebagai phase 0 yang menghubungkan pada riset dan aktivitas pengembangan teknologi lebih lanjut. Keluaran yang dihasilkan dari tahap planning ini adalah project mission statement yang merupakan input yang diperlukan untuk memulai phase pengembangan konsep atau sering pula disebut phase 1 dan sekaligus berfungsi sebagai panduan bagi tim pengembangan produk. Secara lebih detil, keenam phase proses pengembangan produk secara generic tersebut adalah sebagai berikut: 


\section{Phase 0; Planning}

Aktivitas planning seringkali mengacu pada "phase zero" karena mendahului tahap project aproval dan peluncuran proses pengembangan produk yang sesungguhnya. Tahap ini dimulai dengan identifikasi peluang yang dipandu oleh corporate strategy dan termasuk assessment pengembangan teknologi dan tujuan pasar. Keluaran dari tahap planning adalah project mission statement yang menetapkan target pasar untuk produk yang tengah dikembangkan, business goals, key assumptions, dan berbagai batasan dalam proses pengembangan produk.

\section{Phase 1; Concept Development}

Dalam tahap concept development, kebutuhan-kebutuhan dari target market diidentifikasi, berbagai alternatif konsep produk dimunculkan, dievaluasi dan dipilih, selanjutnya satu atau lebih konsep produk dipilih untuk proses pengembangan dan pengujian lebih lanjut. Sebuah konsep rancangan produk merupakan diskripsi dari bentuk, fungsi dan ciri-ciri utama dari sebuah produk yang biasanya disertai sekumpulan spesifikasi, analisis-analisis keunggulan setiap produk dan justifikasi ekonomis dari proyek pengembangan produk tersebut. Dalam proses pengembangan konsep meliputi sejumlah aktivitas yaitu: identifiying customer needs, establishing target specifications, concept generation, concept selection, concept testing, setting final specifications, project planning, economic analysis, benchmarking of competitive products, dan modelling and prototyping

\section{Phase 2; System-level Design}

Tahap system-level design meliputi definisi dari arsitektur produk yang dikembangkan, dekomposisi dari produk ke dalam sejumlah subsistem dan komponen, serta rancangan awal (preliminary design) dari komponenkomponen utama. Rancangan awal dari area sistem produksi dan final assembly biasanya juga didefinisikan pada tahap ini. Keluaran dari tahap ini biasanya meliputi geometric layout dari produk, spesifikasi functional dari setiap subsistem produk, dan preliminary process flow diagram untuk proses final assembly.

\section{Phase 3; Detail Design}

Tahap detail design meliputi spesifikasi lengkap dari produk yang dikembangkan didalamnya termasuk geometri produk, material yang digunakan, toleransi dari seluruh unique part dalam produk dan identifikasi dari seluruh standard part yang harus dibeli dari supplier. Perencanaan proses ditetapkan, tooling dirancang untuk setiap part yang dibuat dalam production system. Keluaran dari tahap ini adalah control documentation dari produk yang dikembangkan, yang di dalamnya meliputi, gambar teknik atau filefile computer yang berisi deskripsi geometri dari setiap part dan peralatan produksi yang digunakan untuk pembuatannya, spesifikasi dari part-part yang dibeli, dan perencanaan proses untuk part-part yang harus dibuat dan dirakit sendiri. Tiga isu penting yang harus diperhatikan selama proses pengembangan produk dan harus diselesaikan dalam tahap detail design adalah pemilihan material yang akan digunakan, biaya produksi, dan ketangguhan performansi (robust performance) dari produk yang dikembangkan.

\section{Phase 4; Testing and Refinement}

Tahap pengujian dan penyempurnaan meliputi proses konstruksi dan evaluasi dari sejumlah versi preproduction/prototype dari produk yang dikembangkan. Prototype awal (versi alpha) biasanya dibangun dengan production-intent parts, yaitu part yang dibuat dengan geometri dan sifat-sifat material yang sama dengan production version dari produk yang dikembangkan, tetapi tidak difabrikasi dengan proses yang sesungguhnya digunakan dalam tahap produksi nantinya. Prototype versi alpha diuji untuk menentukan apakah produk yang dikembangkan dapat berfungsi sesuai dengan rancangan dan memenuhi kebutuhan-kebutuhan inti para customer. Prototype versi beta biasanya dibuat dengan 
proses produksi yang sesungguhnya akan digunakan untuk pembuatan produk, namun belum dirakit dengan sistem perakitan yang sesungguhnya akan digunakan pada final produk. Prototype versi beta akan dievaluasi luas baik secara internal maupun oleh para customer dengan kondisi penggunaan yang sesungguhnya. Tujuan akhir dari prototype versi beta adalah untuk menjawab pertanyaan yang terkait performance dan reliability dari produk yang dikembangkan untuk mengidentifikasi perubahan-perubahan pada level engineering yang diperlukan untuk menghasilkan produk akhir.

\section{Phase 5; Production Ramp-Up}

Pada tahap ini, produk yang dikembangkan dibuat dengan sistem produksi yang secara khusus telah disiapkan untuk produk tersebut. Tujuan utama dari tahap ini adalah untuk memberikan pelatihan pada tenaga kerja sekaligus untuk melihat dan mengatasi apabila masih terdapat persoalanpersoalan pada proses produksi. Produkproduk yang dihasilkan selama tahap ini kadang-kadang diberikan kepada sejumlah customer tertentu dan dievaluasi secara hati-hati untuk melihat seandainya masih terdapat cacat pada produk tersebut. Proses transisi dari tahap production ramp-up menuju tahap produksi penuh biasanya dilakukan secara bertahap. Pada suatu titik dalam tahap transisi tersebut produk diluncurkan dan menjadi tersedia secara luas pada setiap distributor. Sebuah tahap postlaunch project review dapat dilakukan dalam waktu singkat setelah produk diluncurkan. Proses review tersebut meliputi penilaian dan evaluasi proyek pengembangan produk dari sisi komersial dan teknikal, selain itu juga dilakukan untuk melakukan identifikasi kemungkinan melakukan perbaikan pada proses pengembangan produk untuk proyekproyek di masa depan.

\section{Penyesuaian Proses Pengembangan Produk}

Proses pengembangan produk secara umum/generic pada dasarnya adalah proses pengembangan produk yang digunakan dalam market-pull condition bahwa perusahaan memulai proses pengembangan produk berdasarkan peluang pasar yang ada terhadap produk tersebut dan kemudian dengan kemampuan teknologi apapun yang ada berusaha untuk memenuhi kebutuhan pasar tersebut. Oleh karena itu, dalam situasi yang berbeda perlu dilakukan penyesuaian terhadap proses pengembangan produk yang akan dijalankan. Sejumlah situasi yang menuntut dilakukannya penyesuaian proses pengembangan produk tersebut diantaranya adalah perancangan produk dalam kondisi: Technology-Push Products, Platform Products, Process-Intensive Products, Customized Products, High-Risk Products, Quick Build Products, dan Complex Systems.

\section{SIMPULAN}

Buku ini penting untuk dibaca mereka yang tertarik, bekerja, atau mendalami bidang perancangan dan pengembangan produk. Langkah-langkah detil disertai berbagai metode dan tahapan yang digunakan dibahas secara mendalam dalam buku ini. Berbagai contoh-contoh riil dan cerita sukses pengembangan produk semakin memberikan pemahaman yang mendalam terhadap metode-metode pengembangan produk yang dibahas. Buku ini sekaligus dapat menjadi alternatif rujukan yang cukup komprehensif untuk mempercepat perkembangan bidang perancangan dan pengembangan produk karena sepanjang manusia masih hidup didunia ini, maka inovasi akan terus bermunculan, dan produk-produk baru akan terus dilahirkan dan dikembangkan. Manusia akan berusaha keras untuk mewujudkan setiap mimpi-mimpinya akan kehidupan yang lebih baik. Bermula dari mimpi, mewujudkan inovasi. 